\title{
Gaduh Buzzer Politik di Era Jokowi
}

\section{Indrianti Azhar Firdausi. M.Ikom ${ }^{1 *}$, Drs. Media Sucahya.M.Si, Liza Diniarizky P. M.Kesos. M.Ikom' Winata Faturahman. M.Sn, Vilya Dwi Agustini. M.Ikom}

${ }^{1}$ Jalan Raya Serang, Cilegon, Km 5 Kelurahan Drangong Taman Kopasus Serang Banten

*Email korespondensi: indriantiazhar@gmail.com

Kata kunci: Buzzer,

Komunikasi Politik Lasswel, Unsur-unsur Komunikasi Politik

Keyword:

Buzzer,

Political

Communication

Lasswel,

Elements of

Political

Communication

\section{A B S T R A K}

Penelitian ini bertujuan untuk mengetahui komunikasi politik buzzer di era jokowi melalui unsur-unsur komunikasi politik. Buzzer makin dikenal oleh masyarakat melalui media sosial twitter di era jokowi yang selalu eksis pada setiap perhelatan kontestasi politik terutama pada pemilihan presiden. Penelitian ini menggunakan pendekatan kualitatif deskriptif. Data penelitian dikumpulkan melalui observasi dan dokumentasi. Hasil penelitian menunjukkan bahwa buzzer di era Jokowi saat ini memenuhi unsur-unsur komunikasi politik yaitu sebagai komunikator politik yang bertindak sebagai propagandist profesional, pesan politik yang disampaikan bersifat negatif dan politis, media yang digunakan untuk membentuk opini adalah media sosial twitter, khalayak yang disasar adalah kaum muda yang aktif di media sosial, dengan efek yang dapat merusak demokrasi Indonesia dimana buzzer selalu menyerang masyarakat maya yang kontra terhadap pemerintah.

\section{A B STRACT}

This study aims to determine the buzzer political communication in the Jokowi era through elements of political communication. Buzzers are increasingly recognized by the public through social media twitter in the Jokowi era which always exists in every political contestation event, especially in the presidential election. This research uses a descriptive qualitative approach. The research data was collected through observation and documentation. The results show that the buzzer in the Jokowi era currently fulfills the elements of political communication, namely as a political communicator who acts as a professional propagandist, the political messages conveyed are negative and political, the media used to form opinions is Twitter social media, the target audience is young people who are active on social media, with a detrimental effect on Indonesia's democracy where buzzers always attack virtual people who oppose the government.

\section{PENDAHULUAN}

Centre for Innovation and Governance (CIPG) pada tahun 2017 pernah melakukan riset soal sejarah buzzer di Indonesia. Pada awalnya, keberadaan buzzer di media social masih dianggap sebagai hal yang lumrah dan mereka biasa dilibatkan oleh korporat dalam promosi produk. Namun, maknanya menjadi negative karena terlibat dalam peristiwa politik sehingga memberikan citra yang tidak bagus di mata khalayak. Sejak saat itu, buzzer mendapat cap negative sebagai pihak yang dibayar untuk memproduksi konten negative di media social.

Masih menurut CIPG, buzzer adalah individu atau akun yang memiliki kemampuan amplifikasi pesan dengan cara menarik perhatian atau membangun percakapan, lalu bergerak dengan motif tertentu. Buzzer biasanya punya jaringan luas sehingga mampu menciptakan konten sesuai konteks, cukup persuasif dan digerakkan oleh motif tertentu. Singkatnya buzzer adalah pelaku buzzing yang bertugas untuk membuat suara-suara bising seperti dengung lebah.

Saat ini buzzer politik di media social kembali mencuat. Setelah pemilu 2019, para pendengung ini kembali jadi perbincangan karena bergerak aktif ketika terjadi gerakan massa menolak kebijakan pemerintah. Seperti diketahui dilansir dari sejumlah media massa muncul gelombang demonstrasi dan jenis aksi lainnya di sejumlah daerah yang diikuti masyarakat sipil, mulai dari mahasiswa hingga para tokoh masyarakat. Beberapa hal yang menjadi tuntutan masyarakat sipil adalah mencabut UU KPK hasil revisi dan menerbitkan peraturan pemerintah pengganti undang-undang (perppu) terhadap UU KPK 
hasil revisi. Kemudian menolak pelemahan pemberantasan korupsi, RKUHP, RUU Permasyarakatan, RUU MInerba, RUU Sumber Daya Air, RUU Ketenagakerjaan, pencemaran Agama (Islam Agama Arogan), ujaran kebencian terhadap Rocky Gerung, ujaran rasisme terhadap eks Komisioner Komnas HAM Natalius Pigai dan masih banyak lagi. Selain itu, mereka juga mendesak disahkannya RUU penghapusan Kekerasan Seksual hingga tuntaskan berbagai kebakaran hutan dan lahan. Di sisi lain, para pendengung ini menyebarkan narasi-narasi yang bersebrangan dengan yang diperjuangkan masyarakat sipil. Media social pun menjadi risuh dan keruh yang berujung pada pelaporan masyarakat kepada pihak berwajib.

Munurut Peneliti Pusat Studi Hukum dan Kebijakan (PSHK), buzzer beresiko membangun perdebatan yang tidak produktif dan tidak sehat karena mereka menyebarkan narasi yang bersifat menyudutkan. Para buzzer dapat dengan mudah menggeser perdebatan ke hal-hal yang tidak substansial. Dengan demikian perhatian publik akan teralihkan, mereka bisa melakukan itu dengan berbagai narasi dan memutarkbalikan fakta. Hal ini berujung pada pelaporan-pelaporan komunitas masyarakat sipil terhadap narasi para buzzer yang dianggap meresahkan dan memecahbelah. Terdapat dua pola tugas buzzer diantaranya bertugas untuk memaki-maki adan yang bertugas melaporkan ke kepolisian terkait postingan masyarakat yang mengkritik pemerintah.

Salah satu buzzer aktif yaitu Permadi Arya atau dikenal dengan Abu janda, mengaku mulai giat di media social sejak 2015. Dia membuat beragam parodi untuk melawan teorisme ISIS dan radikalisme yang berkembang, khususnya di media social. Tak Cuma itu, belakangan dia juga aktif menyerang balik pihak-pihak yang dianggapnya kerap menyerang Presiden Jokowi. Dengan pertimbangan kerativitas, keberpihakan dan keberaniannta itulah pada 2018, tim sukses Jokowi mengajaknya bergabung. Abu Janda dan sejumlah buzzer lainnya menjadi buzzer selama kampanye pilpres 2019 hingga saat ini.

Kegiatan posting, retweet, share dan like yang dilakukan oleh buzzer cukup membuat gaduh masyarakat, bermunculan opini-opini tokoh yang menganggap kehadiran buzzer hanya memperkeruh kondisi Indonesia. Sehingga beberapa kali Abu janda dan buzzer lainnya harus berususan dengan hukum meskipun selalu lepas

Dalam komunikasi politik, buzzer menjadi bagian dari komunikator politik yang membawa pesan dan memiliki pengaruh terhadap masyarakat untuk membentuk citra kandidatnya. Buzzer termasuk komunikator politik professional yang mengendalikan keterampilan yang khas dalam mengolah symbol-simbol dan yang memanfaatkan keterampilan ini untuk menempa mata rantai yang menghubungkan orang-orang yang jelas perbedannya atau kelompok-kelompok yang dibedakan. James Carey dalam Dan Nimmo 1989 mengatakan bahwa komunikator professional adalah makelar symbol yang menerjemahkan sikap, pengetahuan, dan minat suatu komunitas.

\section{METODE PENELITIAN}

Penelitian ini menggunakan pendekatan kualitatif. Menurut Denzin dan Lincoln menyatakan bahwa penelitian kualitatif adalah penelitian yang menggunakan latar alamiah dengan maksud menafsirkan fenomena yang terjadi dan dilakukan dengan melibatkan berbagai metode (Moleong, 2009:5). Selain itu menurut Bogdan dan Taylor mendefinisikan metodologi kualitatif sebagai prosedur penelitian yang menghasilkan data deskriptif berupa kata-kata tertulis atau lisan dari orangorang dan perilaku yang dapat diamati (Moleong, 2009:4). Dari defisini tersebut Nazir (2005) menjelaskan penelitian deskriptif adalah studi untuk menemukan fakta dengan interpretasi yang tepat, melukiskan secara tepat sifat-sifat dari beberapa fenomena kelompok atau indivisu, menentukan frekuensi terjadinya suatu keadaan untuk meminimalkan bias dan memaksimalkan reabilitas. Analisanya dikumpulkan setelah semua kejadian berlangsung (Nazir, 2005:105). Tujuan penelitian deskriptif adalah untuk menggambarkan secara tepat sifat-sifat individu, keadaan, gejala atau kelompokkelompok tertentu atau menemukan penyebaran (frekuensi) suatu gejala dan gejala lainnya dalam masyarakat.

Teknik pengumpulan data dalam penelitian ini, yaitu:

\section{Observasi}


Beberapa bentuk observasi menurut Burhan Bungin (2007:115-117) yaitu pertama, observasi partisipasi adalah metode pengumpulan data yang digunakan untuk menghimpun data penelitian melalui pengamatan dan penginderaan di mana peneliti terlibat dalam keseharian informan. Kedua, observasi tidak terstruktur ialah pengamatan yang dilakukan tanpa menggunakan pedoman observasi, sehingga peneliti mengembangkan pengamatannya berdasarkan perkembangan yang terjadi di lapangan. Ketiga, observasi kelompok ialah pengamatan yang dilakukan oleh sekelompok tim peneliti terhadap sebuah isu yang diangkat menjadi objek penelitian. Berdasarkan hal tersebut, peneliti menggunakan teknik observasi kelompok.

\section{Dokumentasi}

Teknik atau studi dokumentasi adalah cara pengumpulan data melalui peninggalan arsip-arsip termasuk juga buku-buku tentang pendapat, teori, dalil-dalil atau hukum-hukum dan lain-lain berhubungan dengan masalah penelitian. Dalam penelitian kualitatif teknik pengumpulan data yang utama karena pembuktian hipotesisnya yang diajukan secara logis dan rasional melalui pendapat, teori atau hukum-hukum, baik mendukung maupun menolak hipotesis tersebut (Dimyati, 2014:19)

Teknik analisis yang digunakan dalam penelitian ini adalah analisis deskriptif kualitatif. Teknik analisa data ini menguraikan, menafsirkan dan menggambarkan data yang terkumpul secara sistemik dan sistematik. Untuk menyajikan data tersebut agar lebih bermakna dan mudah dipahami adalah menggunakan interactive model analysis dan Miles dan Huberman (1992:16).

\section{Komunikasi Politik}

Istilah komunikasi politik menunjuk kepada pesan sebagai objek formalnya, sehingga titik berat konsepnya terletak pada komunikasi dan bukan pada politik. Pada hakekatnya komunikasi politik mengandung informasi atau pesan tentang politik. Menurut Nimmo dalam buku Komunikasi Politik (Komunikator, Pesan dan Media) (56:2019), banyak aspek kehidupan politik dapat dilukiskan sebagai komunikasi, bahkan komunikasi meliputi politik terdapat tiga jenis pembicaraan memiliki kepentingan politik di dalamnya, yaitu pembicaraan kekuasaan, pembicaraan pengaruh, dan pembicaraan otoritas, Nimmo tambahkan satu lagi pembicaraan yang mengandung arti politik yaitu pembicaraan tentang konflik. Dalam hal ini buzzer berusaha masuk dalam sebuah konflik untuk menggiring opini publik sehingga pecah suara dan keberpihakan masyarakat melalui opini-opini frontal buzzer mengenai pihak-pihak yang mereka bela secara politis.

Dalam penelitian Nimmo yang berjudul Komunikasi Politik dan Pendapat Umum di Amerika, ia menggunakan formula Lasswell dalam menjelaskan luas lingkup komunikasi politik, yaitu komunikator politik, pesan politik, media komunikasi politik, khalayak politik dan efek politik. Dalam penelitian ini maka lingkup komunikasi politik buzzer mencakup keseluruhan lingkup komunikasi politik. Begitu juga dengan penelitian ini akan menjelaskan lingkup komunikasi politik buzzer sebagai komunikator politik, pesan apa yang disampai buzzer, melalui media apa buzzer dalam berkomunikasi politik, siapa khalayaknya dan apa efek politiknya.

\section{HASIL DAN PEMBAHASAN \\ Sejarah Buzzer}

Sejarah penggunaan buzzer di Indonesia diawali dengan media sosial Twitter mulai lahir pada tahun 2006 dan mulai digunakan di Indonesia, kemudian fungsi buzzer mulai digunakan untuk kepentingan promosi pada brand-brand produk tertentu. Sementara itu awal keterlibatan buzzer dalam peristiwa politik yaitu pada pemilihan gubernur DKI pada tahun 2012, saat itu tim pemenangan pasangan jokowi-ahok sudah mulai memanfaatkan keberadaaan buzzer untu mendongkrak citra dan menjatuhkan lawan politik. Dua tahun kemudian tepatnya pada tahun 2014, buzzer mulai digunakan secara luas untuk kepentingan politik. Diantaranya Jokowi dinyatakan unggul atas Prabowo dalam berbagai survei sehingga terjadi 'perang " di media sosial. Terutama dalam pemilihian presiden dengan pasangan Joko Widodo-Jusuf Kalla dan Prabowo Subianto-Hatta Rajasa. Dirasa berhasil menjatuhkan oposisi melalui penggiringan opini yang dilakukan para buzzer.

Maka pada pemilihan gubernur DKI Jakarta tahun 2017 para buzzer dipakai kembali untuk kepentingan politik. Di pilpres 2019 buzzer makin meningkatkan intensitasnya dalam menyebarkan isu-isu Para buzzer yang 
terlibat langsung dalam kanpanye saat ini menggambarkan bagaimana mereka mengoperasikan ratusan akun media sosial yang dipersonalisai masing-masing atas nama kandidat. Satu membantah menyebarkan berita palsu, sementara dua mengatakan mereka tidak peduli tentang keakuratan konten. Pakar siber mengatakan, kampanye buzzer telah jauh melampaui upaya Facebook dan perusahaan media sosial lainnya untuk mengurangi penciptaan akun palsu dna menyebarkan berita palsu. Proporsi hoaks lebih besar menargetkan jokowi, yang digambarkan sebagai sosok antiIslam, antek China, atau komunis. Sementara hoaks yang menyasar Prabowo Subianto porsinya lebih kecil.

\section{Komunikasi Politik Buzzer}

a. Komunikator politik Buzzer

Posisi buzzer sebagai komunikator politik masuk dalam bertindak sebagai profesional dimana mereka merupakan makelar simbol yang menerjemahkan sikap, pengetahuan dan minat dalam istilah-istilah yang dikenal oleh masyarakat sehingga apa yang disampaikan mudah diterima dan dicerna oleh khalayak.

Sementara dalam buku Problematika Komunikasi Politik (2018) karya Gun Gun Heryanto mengidentifikasi perspektif komunikasi politik yang membagi empat tipologi pertama dissemanator yaitu menyebar informasi harian dengan pola berbagi dan terkoneksi satu sama lain tujuan agar ide, ajakan atau sikapnya diketahui dan bisa diikuti orang lain, kedua pulicst, biasanya membangun citra positif untuk tujuan popularitas dengan kontestasi politik seperti pemasaran politik melalui media sosial, ketiga propagandist, senantiasa mempraktikkan teknik-teknik propaganda guna kepentingan delegitimasi lawan sekaligus memperkuat legitimasi dirinya lewat internet, keempat hactivist, yaitu aktivitas utamanya adalah meretas dan membobol akun. Berdasarkan hal tersebut maka buzzer sebagai komunikator politik merupakan propagandist profesional yang memiliki pola komunikasi terstruktur sesuai dengan momen yang dapat dipolitisasi dan menggiring opini publik. Buzzer politik profesional ini bekerja secara profesional yang memiliki jumlah pengikut media sosial yang lebih banyak, terorganisir, dan memiliki bayaran yang besar. Seperti buzzer Permadi Arya atau yang lebih di kenal
Abu Janda yang mengaku dibayar bulanan dengan nominla besar tapi ia tak menyebut berapa besaran rupiah yang diterimanya. Namun selesai pilpres kontraknya tidak diperpanjang.

\section{b. Pesan Politik Buzzer}

Buzzer merupakan sosok akun media sosial baik anonim atau nyata yang setiap saat menyebarluaskan, mengkampanyekan, mendengungkan suatu pesan atau konten dengan tujuan memperkuat suatu pesan atau konten tersebut menjadi opini publik. Pesan atau konten bisa berupa informasi, produk dan jasa kepada warganet. Dengan kata lain buzzer media sosial lebih identik dengan upaya memperkuat suatu pesan (Arianto, 2019).

Buzzer terindikasi memanfaatkan secara luas dunia maya untuk menyampaikan opiniopini yang terdengar berbeda atau memihak terhadap salah satu tokoh politik yang sedang bertarung di panggung pemilihan umum baik tingkat kepala daerah maupun Presiden. Namun yang lebih ramai pada pilpres, selain ramai di situasi politik buzzer juga ikut memanaskan isuisu yang sifatnya menyudutkan pemerintah maka mereka akan berbalik membela pemerintah. Buzzer dimanfaatkan secara luas dalam dunia politik ketika adanya Pemilihan Presiden (Pilpres 2014) dan jasa buzzer mulai dilirik oleh aktor-aktor politik. Pesan kampanye yang disebarkan oleh buzzer politik yang cenderung merupakan kampanye negatif dan bukan kampanye positif. Hal ini memunculkan berita-berita hoax dan memicu perselisihan, mulai dari menyerang kebijakan hingga masalah pribadi dari masing-masing calon presiden. Apa yang disampaikan buzzer yang intens diharapkan menggiring opini masyarakat dalam menentukan pilihannya.

\section{c. Media komunikasi politik Buzzer}

Peran buzzer awalnya digunakan dalam mempromosikan sebuah brand produk dalam media sosial seperti platform twitter, kemudian merambah ke instagram kemudian beralih ke facebook. Namun para buzzer tetap menggunakan twitter karena platform tersebut masih memegang kendali dikarenakan informasi dalam twitter lebih cepat beredar dan juga memiliki fasilitas trending topik yang tidak dimiliki media sosial lainnya. Ini diperkuat kondisi yang menunjukkan Indonesia merupakan Negara Asia dengan pengguna twitter aktif 5,6 juta pengguna. Angka yang 
memposisikan Indonesia dalam urutan pertama pengguna twitter di Asia (lpmpjateng.go.id).

Jika akan membuat suuatu isu politik atau membuat counter narasi terhadap pernyataan dari lawan politiknya, buzzer biasanya akan membuat tagar berisikan kalimat tertentu. Lalu mencuitkan percakapan yang mengajak pengikutnya untuk mendukung aksinya. Penggunaan tagar bertujuan untuk mendapatlam predikat trending topics, sehinnga tagar yang sudah termuat misi mereka dapat dilihat oleh orang banyak.

\section{d. Khalayak Buzzer}

Khalayak muda baik remaja maupun dewasa adalah audiens aktif yang mendominasi penggunaan teknologi yang terus berkembang saat ini. Sebagaimana data kekominfo, usia di bawah 34 tahun merupakan pengguna terbanyak yang memanfaatkan kreativitas informasi. Golongan ini dianggap potensial menjadi sasaran komunikasi politik buzzer. Buzzer politik dianggap mampu membangun citra kandidat. Realitas ini tergambar dalam masa kampanye pemilihan gubernur Daerah Ibu Kota Jakarta yang dilakukan kandidat pasangan Joko Widodo dan Ahok dengan akun twitter@jokowi_do2. Penggunaan twitter buzzer dianggap berhasil menjangkau pemilih untuk kategori khalayak muda. Hingga terpilih sebagai gubernur buzzer Jokowi masih tetap ada sampai dengan posisinya sebagai Presiden dan strategi pengguaan buzzer dalam setiap kampanye nya selalu berhasil mengantarkannya dalam setiap pemilihan termasuk pemilihan presiden. Kesuksesan tersebut diikuti beberapa aktor politik maupun tokoh pemerintah lainnya untuk melakukan pendekatan dan membangun keterlibatan dengan masyarakat, seperti akun twitter@SBYudhoyono yang lahir pada April 2013.

Aktifnya buzzer di media sosial untuk menjangkau kalangan muda yang aktif di media sosial dan kalangan yang paling mudah digiring opininya tentang politik.

\section{e. Efek Komunikasi Politik Buzzer}

Komunikator politik memiliki peran sosial utama dalam proses opini publik. Karl Popper mengemukakan bahwa ada teori opini publik yang seluruhnya dibangun sekitar komunikator politik. Hal ini ditegaskan bahwa para pemimpin menciptakan opini publik karena mereka berhasil membangun beberapa gagasan yang diterima, meskipun awalnya sempat ditolak. Karena itu, opini publik dipahami sebagai tanggapan terhadap gagasan dan usaha komunikator dalam menyakinkan publik. Mereka yang menjadi komunikator politik bisa berasal darimana saja. Dilansir dari sindonews.com bahwa ilmuwan Universitas Oxford Samantha Bradshaw dan Philip Howard menerbitkan hasil riset berjudul "The Global Disinformation Order, 2019 Global Inventory of Organised Social Media Manipultaion" bahwa pemerintah dan partai politik Indonesia membayar pasukan siber atau buzzer untuk memanipulasi opini publik.

Buzzer yang terorganisir oleh pemerintah akan berdampak rusaknya iklim demokrasi di Indonesia jika tidak ditertibkan selepas pilpres. Namun buzzer masih dalam ranahnya sebagai pendengung dan bagian dari oposisi pemerintah setiap kali isu-isu kebijakan pemerintah muncul.

\section{Kesimpulan}

Keberadaaan buzzer memberi warna pada dunia politik meskipun dalam situasi yang diciptakan membuat gaduh perpolitikan terutama pada saat pilpres. Dalam komunikator politik, buzzer menjadi propagandist profesional yang di kontrak untuk menggiring opini masyarakat kepada salah satu calon dalam kontestasi kepala daerah maupun pemilihan presiden. Sementara pesan politik yang disampaikan buzzer menyebarkan suatu konten untuk menguatkan suatu pesan politik yang sifatnya negatif untuk menggiring opini masyarakat. Selain itu media yang digunakan oleh buzzer politik dominan melalui media sosial twitter karena di media sosial tersebut terdapat tagar yang dapat disebarluaskan dalam waktu yang cepat sehingga viral dan menjadi perbincangan masyarakat maya. Sementara khalayak yang disasar oleh para buzzer adalah khalayak muda yang aktif di media sosial, mereka dianggap khalayak yang mudah diarahkan pandangan dan opini politiknya. Efek dari kehadiran buzzer dalam ranah politik akan merusak jalannya demokrasi di Indonesia jika tidak dibatasi pergerakannya, karena setiap kebijakan pemerintah yang mendapat reaksi kontra dari masyarakat akan dihalau oleh para buzzer sehingga masyarakat khawatir suara mereka teredam oleh kicauan buzzer yang telah menjadi trending topic. 


\section{References}

Arianto. B. (2019). Buzzer Media Sosial dan Branding Produk UMKM Daerah Istimewa Yogyakarta. Jurnal UMKM Dewantara. 2, (1) 27-46.

Bungin, Burhan. (2007). Penelitian Kualitatif. Komunikasi, Ekonomi, Kebijakan Publik dan Ilmu Sosial Lainnya. Putra Grafika. Jakarta.

Bradshaw, Samantha, dan Phillip Howard. (2019). The Global Disinformation Order, 2019 Global Inventory og Organized Social Media Manipulation. Oxford University. (2017). Centre for Innovation and Government.
Heryanto, Gun-Gun.(2018) Problematika Komunikasi Politik. Ircisod. Jakarta

Moleong, Lexy J. (2007). Metodologi Penelitian Kualitatif. Remaja Rosdakarya Offset. Bandung

Nimmo, Dan.(2019). Komunikator, Pesan dan Media. Remaja Rosdakarya Offset. Bandung

Nazir, Moh. (2005). Metodologi Penelitian Kualitatif. Ghalia Indonesia. Jakarta.

Sugiono, Shiddiq. (2020). Fenomena Industri Buzzer di Indonesia: Sebuah Kajian Ekonomi Politik Media. Jurnal Communicatus: Jurnal Ilmu Komunikasi. 4, (1), 47-66. 